BENHA VETERINARY MEDICAL JOURNAL, VOL. 31, No. 2:213-219, DECEMBER, 2016

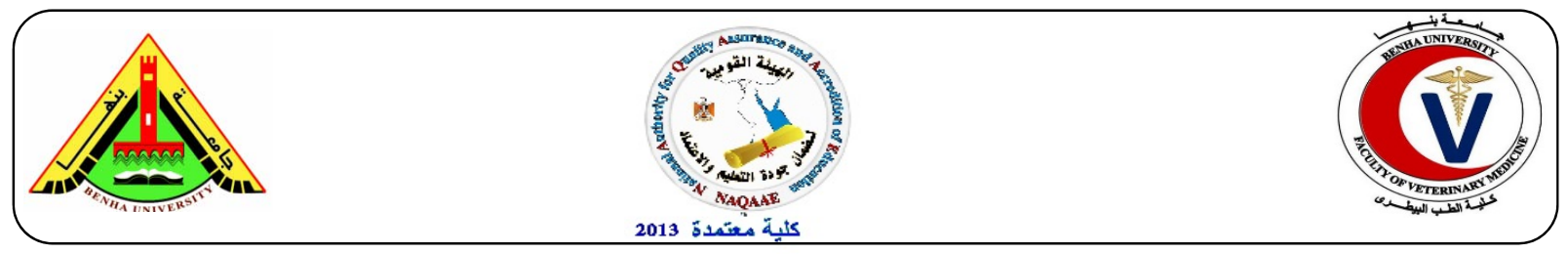

\title{
Prevalence of some foodborne microorganisms in meat and meat products.
}

\author{
${ }^{1}$ Fahim, A. Shaltout, ${ }^{2}$ Ahmed, A. A. Maarouf, ${ }^{3}$ Ibrahim, A. El-Kewaiey and ${ }^{4}$ Ahmed, Y. A. \\ Heweidy
}

${ }^{1}$ Food Control Department (Meat Hygiene), Fac. Vet. Med. Benha Univ. ${ }^{2}$ Animal Health Research "Benha branch". ${ }^{3}$ Animal Health Research "Damanhour branch". ${ }^{4}$ Vet. at Shubra-Bokhom Abattoir

\section{A B S T R A C T}

This study was conducted on 140 random samples of fresh beef and meat products viz: minced meat, luncheon and sausage (35 for each), collected from different shops at El-Kaliobia Governorate, to evaluate their bacteriological profile. The bacteriological examination of fresh beef and meat products minced meat, sausage and luncheon revealed that the mean values of APC, Enterobacteriaceae, coliform and Staphylococcus counts were $8.34 \times 10^{4} \pm 0$. $10 \times 10^{4}$; $2.14 \times 10^{2} \pm 0.97 \times 10^{2} ; 1.25 \times 10^{2} \pm 0.13 \times 10^{2}$ and $2.36 \times 10^{2} \pm 0.12 \times 10^{2}$ for fresh beef samples; $8.03 \times 10^{4} \pm 0.12 \times 10^{4} ; 2.02 \times 10^{2}$ $\pm 0.76 \times 10^{2} ; 0.89 \times 10^{2} \pm 0.06 \times 10^{2}$ and $2.67 \times 10^{2} \pm 0.11 \times 10^{2}$ for minced meat samples; $6.74 \times 10^{4} \pm 0.28 \times 10^{4} ; 1.85 \times 10^{2}$ $\pm 0.64 \times 10^{2} ; 0.73 \times 10^{2} \pm 0.08 \times 10^{2}$ and $1.9 \times 10^{2} \pm 0.11 \times 10^{2}$ for sausage samples and $5.85 \times 10^{4} \pm 0.24 \times 10^{4} ; 1.69 \times 10^{2}$ $\pm 0.70 \times 10^{2} ; 0.71 \times 10^{2} \pm 0.07 \times 10^{2}$ and $1.68 \times 10^{2} \pm 0.11 \times 10^{2}$, for luncheon samples. Further, 21 isolates of E.coli were isolated from examined meat samples represented as 5(14.3\%) from fresh beef with serotypes 2 O55:H7,1 O125:H18,1 O111: H4 and $1 \mathrm{O} 26: \mathrm{H} 11 ; 8(22.9 \%)$ from minced meat with serotypes 3 O55:H7, 2 O125:H18, 1 O111:H4, 1 O26:H11 and 1 untyped; 6 (17.1\%) from sausage with serotypes 2 O55:H7, 1 O125:H18, 1 O111:H4, 1 O26:H11 and one untyped and $2(5.7 \%)$ from luncheon samples with serotypes $\mathrm{O} 55: \mathrm{H} 7$. In addition, 25 isolates of Coagulase positive S. aureus were isolated from examined meat samples represented as $6(17.1 \%)$ from fresh beef; $9(25.7 \%)$ from minced meat; 7 (20.0\%) from sausage and 3(8.6\%) from luncheon samples. Meanwhile, Salmonella serovars were not detected from all examined meat samples.

Key words: Meat products, bacteriological evaluation, E. coli, Staph. aureus, Salmonella

(http://www.bvmj.bu.edu.eg)

(BVMJ-31(2): 213-219, 2016)

\section{INTRODUCTION}

Food borne diseases caused mainly by E. coli, Salmonella species and $S$. aureus are the major causes of mortality and infections especially in the developing countries. These pathogens are transmitted mainly through consumption of contaminated food and the presence of these organisms in meat and raw meat products has relevant public health implications (Zafar et al., 2016). The bacterial contamination and hygienic measures during meat production can be measured using the aerobic plate count, total Enterobacteriaceae, total coliforms and Escherichia coli. (Aberle et al., 2000; Hamed et al., 2015; McEvovy et al., 2004). E. coli is considered as a good indicator of possible fecal contamination (Synge, 2000). It is commonly non-virulent but some strains have adopted pathogenic or toxigenic virulence factors that make them pathogenic to human and animals. It has been associated with numerous out breaks of disease resulting from contaminated beef and meat products, including bacteremia, urinary tract infections, neonatal meningitis, pneumonia, deep surgical wound infections, endovascular infections, vertebral osteomyelitis, and septicemia (Datta et al., 2012; Gi et al., 2009; Kaper et al., 2004 ; Madden et al., 2001). Infections with Salmonellae and coagulase positive $S$. aureus, are the causative agents of two thirds of food-borne disease outbreaks causing gastroenteritis and rarely acquired directly from raw meat but mostly occurs either due to excessive handling or contamination during or after cooking of meat and meat products (Busani et al., 2005; Khan et al., 2014; Leloir et al., 2003). Staphylococci produce some enzymes which are implicated with Staphylococcus invasiveness and many extracellular substances some of which are heat stable enterotoxins that renders the food dangerous even though it appears normal and extensive cooking can be killed the bacteria but the toxins may not be destroyed because most of them are gene based i.e. they can be carried on the plasmid (Prescott et al., 2005 ). The enterotoxins are produced by about one-third of coagulase 
positive Staph. aureus strains and growth of enterotoxigenic strains of Staph. aureus to population of at least $10^{5} \mathrm{cfu} / \mathrm{g}$ in food is generally considered necessary for production of sufficient amount of enterotoxins to induce food intoxication (Park et al., 1994). The Staphylococcal enterotoxins (SEs) are responsible for the symptoms. The disease is characterized by symptoms including nausea, vomiting, abdominal cramps and diarrhea lasting from 24 to $48 \mathrm{~h}$ and the complete recovery usually occurs within 1-3 days (Llewelyn and Cohen, 2002). Moreover, SEA is the most common enterotoxin recovered from food poisoning outbreaks (Balaban and Rasooly, 2000). As the level of contamination of beef and its products with different food-borne pathogens constitutes serious problems for consumers, so, the present study was conducted to evaluate the safety and quality of beef and common meat products (minced meat; sausage and luncheon) at Kaliobia Governorate.

\section{MATERIAL AND METHODS}

\subsection{Samples collection:}

A total of 140 random samples of fresh beef and meat products viz: Minced meat, luncheon and sausage (35 for each), were collected from different shops at Kaliobia Governorate. To evaluate the bacterial status and detection of some food borne pathogens containing them.

\subsection{Bacteriological examination}

1. Preparation of samples (American Public Health Association "APHA", 1992).

2. Determination of Aerobic Plate Count (APC)/ $\mathrm{g}$, using the standard plate count following (Food and Drug Administration "FDA", 2001).

3. Determination of Total Enterobacteriaceae count by the surface plating method of ICMSF (1996) using Violet Red Bile Glucose agar medium (VRBG).

4. Total coliform count by the surface plating method of ICMSF (1996) using Violet Red Bile agar medium.

5. Isolation and identification of E.coli followingInternational Organization of Standardization "ISO" (2001) : Typical E.coli colonies (pink - orange colonies) were picked up for identification morphologically by Gram stain; biochemically, serologically by slide agglutination test (using E.coli antisera "SEIKEN" Set 1, consists of 8 polyvalent and
43 (OK) antisera of DENKA SEIKEN Co. LTD. Tokyo, Japan) following Edward and Ewing ( 1972) and Quinn et al. (2002).

6. Determination of Total Staphylococci count following ICMSF (1996)

7. Isolation of Staph. aureus using Baird-Parker Agar Plates. Suspected colonies were picked up onto slants of nutrient agar for further purification then identified morphologically by Gram-stain; biochemically and coagulase activities according to ICMSF (1996) and Quinn et al., (2002)

8. Isolation and identification of Salmonella following ISO (2002). Suspected Salmonella colonies that appeared as red with black centers on XLD agar were identified morphologically by Gram-stain and biochemically according to Quinn et al. (2002).

\subsection{Statistical analysis:}

Data obtained were analyzed according to Snedecor and Cochran (1969) using the computer software program (SPSS, 2001).

\section{RESULTS}

The results of bacteriological examination of fresh beef and meat products revealed that APC, coliform and enterobacteriaceae were highest in fresh beef then minced meat then sausage then luncheon. While, staphylococcal count was highest in minced meat then fresh beef then sausage then luncheon, in which the incidence of coagulase positive Staph. aureus is highest in minced meat then sausage then fresh beef then luncheon. Isolation and identification of $E$. coli in the examined samples revealed that the incidence of $E$. coli was highest in minced meat followed by sausage then fresh beef then luncheon, strains of $E$. coli identified as $\mathrm{O}_{55}: \mathrm{H}_{7}, \mathrm{O}_{125}: \mathrm{H}_{18}, \mathrm{O}_{111}: \mathrm{H}_{4}, \mathrm{O}_{26}: \mathrm{H}_{11}$, noticed that two samples were untypable. Salmonella serovars were failed to be detected in all examined samples of fresh beef and meat products.

\section{DISCUSSION}

Food borne diseases caused by E. coli, Salmonella species and Staph. aureus that transmitted mainly through consumption of contaminated food and the presence of them in meat and raw meat products has relevant public health implications 
Table (1): Aerobic plate counts /g. (APC) in the examined samples of fresh beef and meat products $(\mathrm{n}=35$ for each product)

\begin{tabular}{llllll}
\hline Sample & \multicolumn{2}{l}{$\begin{array}{l}\text { Positive } \\
\text { No. }\end{array}$ \%* } & Min. & Max. & Mean \pm SEM $^{* *}$ \\
& 35 & 100 & $7.3 \times 10^{4}$ & $9.9 \times 10^{4}$ & $8.34 \times 10^{4} \pm 0.10 \times 10^{4 \mathrm{a}}$ \\
\hline Fresh beef & 35 & 100 & $6.5 \times 10^{4}$ & $9.5 \times 10^{4}$ & $8.03 \times 10^{4} \pm 0.12 \times 10^{4 \mathrm{a}}$ \\
Minced meat & 35 & 100 & $2.8 \times 10^{4}$ & $8.9 \times 10^{4}$ & $6.74 \times 10^{4} \pm 0.28 \times 10^{4 \mathrm{~b}}$ \\
Sausage & 35 & 100 & $2.5 \times 10^{4}$ & $7.9 \times 10^{4}$ & $5.85 \times 10^{4} \pm 0.24 \times 10^{4 \mathrm{c}}$ \\
Luncheon & Percentage in relation to total number of sample in each row. ${ }^{* *}$ Standard error of mean
\end{tabular}

Table (2): Enterobacteriaceae counts/g. in the examined samples of fresh beef and meat products $(\mathrm{n}=35$ for each product)

\begin{tabular}{llllll}
\hline Sample & \multicolumn{2}{l}{ Positive } & Min. & Max. & Mean \pm SEM $^{* *}$ \\
& No. & $\% *$ & & & \\
\hline Fresh beef & 34 & 97.1 & $1.2 \times 10^{2}$ & $3.3 \times 10^{2}$ & $2.14 \times 10^{2} \pm 0.97 \times 10^{2 \mathrm{a}}$ \\
Minced meat & 34 & 97.1 & $1.1 \times 10^{2}$ & $2.9 \times 10^{2}$ & $2.02 \times 10^{2} \pm 0.76 \times 10^{2 \mathrm{ab}}$ \\
Sausage & 34 & 97.1 & $1.2 \times 10^{2}$ & $2.7 \times 10^{2}$ & $1.85 \times 10^{2} \pm 0.64 \times 10^{2 \mathrm{bc}}$ \\
Luncheon & 34 & 97.1 & $1.0 \times 10^{2}$ & $2.6 \times 10^{2}$ & $1.69 \times 10^{2} \pm 0.70 \times 10^{2 \mathrm{c}}$ \\
\hline * Percentage in relation to total number of sample in each row $* *$ Standard error of mean
\end{tabular}

Table (3): Coliforms counts/g. in the examined samples of fresh beef and meat products $(\mathrm{n}=35$ for each product)

\begin{tabular}{llllll}
\hline Sample & \multicolumn{2}{l}{ Positive } & Min. & Max. & Mean \pm SEM $^{* *}$ \\
& No. $\% *$ & & & \\
\hline Fresh beef & 14 & 40.0 & $0.6 \times 10^{2}$ & $2.1 \times 10^{2}$ & $1.25 \times 10^{2} \pm 0.13 \times 10^{2 \mathrm{a}}$ \\
Minced meat & 15 & 42.9 & $0.5 \times 10^{2}$ & $1.3 \times 10^{2}$ & $0.89 \times 10^{2} \pm 0.06 \times 10^{2 \mathrm{~b}}$ \\
Sausage & 13 & 37.1 & $0.3 \times 10^{2}$ & $1.1 \times 10^{2}$ & $0.73 \times 10^{2} \pm 0.08 \times 10^{2 \mathrm{~b}}$ \\
Luncheon & 13 & 37.1 & $0.3 \times 10^{2}$ & $1.2 \times 10^{2}$ & $0.71 \times 10^{2} \pm 0.07 \times 10^{2 \mathrm{~b}}$ \\
\hline * Percentage in relation to total number of sample in each row. **Standard error of mean
\end{tabular}

Table (4): Incidence of $E$. coli in examined samples of fresh beef and meat products ( $\mathrm{n}=35$ for each product)

\begin{tabular}{lllll}
\hline Sample & \multicolumn{2}{l}{ Positive } & No. of accepted samples** & No. of non- accepted samples** \\
& No. & $\% *$ & & \\
\hline Fresh beef & 5 & 14.3 & 30 & 5 \\
Minced meat & 8 & 22.9 & 27 & 8 \\
Sausage & 6 & 17.1 & 29 & 6 \\
Luncheon & 2 & 5.7 & 33 & 2 \\
Total & 21 & 15.0 & 119 & 21 \\
\hline
\end{tabular}

* Percentage in relation to total number of sample in each row. **Accepted and non- accepted samples according to (EEC, 2005).

Table (5): Incidence and serotyping of E. coli isolated from positive samples of fresh beef and meat products $(\mathrm{n}=35$ for each product)

\begin{tabular}{llllllllll}
\hline Sample & \multicolumn{2}{l}{ Fresh beef } & \multicolumn{2}{l}{ Minced meat } & \multicolumn{2}{l}{ Sausage } & \multicolumn{2}{l}{ Luncheon } & Strain \\
E. coli serotype & No. & $\% *$ & No. & $\%^{*}$ & No. & $\% *$ & No. & $\%^{*}$ & characteristic \\
\hline O55:H7 & 2 & 5.71 & 3 & 8.57 & 2 & 5.71 & 2 & 5.71 & EPEC \\
O125:H18 & 1 & 2.86 & 2 & 5.71 & 1 & 2.86 & 0 & 0.00 & EPEC \\
O111:H4 & 1 & 2.86 & 1 & 2.86 & 1 & 2.86 & 0 & 0.00 & EHEC \\
O26:H11 & 1 & 2.86 & 1 & 2.86 & 1 & 2.86 & 0 & 0.00 & EPEC \\
Untyped & 0 & 0.00 & 1 & 2.86 & 1 & 2.86 & 0 & 0.00 & - \\
Total & 5 & 14.29 & 8 & 22.86 & 6 & 17.14 & 2 & 5.71 & - \\
\hline
\end{tabular}

* Percentage in relation to total number of each sample (35). EPEC: Enteropathogenic E. coli EHEC: Enterohaemorrhagic E. coli 
Table (6): Staphylococci counts/gm. in the examined samples of fresh beef and meat products ( $\mathrm{n}=35$ for each product)

\begin{tabular}{|c|c|c|c|c|c|}
\hline \multirow[t]{2}{*}{ Sample } & \multicolumn{2}{|c|}{ Positive } & \multirow[t]{2}{*}{ Min. } & \multirow[t]{2}{*}{ Max. } & \multirow[t]{2}{*}{ Mean $\pm \mathrm{SEM}^{* *}$} \\
\hline & No. & $\% *$ & & & \\
\hline Fresh beef & 34 & 97.1 & $0.7 \times 10^{2}$ & $3.8 \times 10^{2}$ & $2.36 \times 10^{2} \pm 0.12 \times 10^{2 \mathrm{a}}$ \\
\hline Minced meat & 34 & 97.1 & $1.1 \times 10^{2}$ & $3.8 \times 10^{2}$ & $2.67 \times 10^{2} \pm 0.11 \times 10^{2 a}$ \\
\hline Sausage & 33 & 94.3 & $0.7 \times 10^{2}$ & $3.3 \times 10^{2}$ & $1.9 \times 10^{2} \pm 0.11 \times 10^{2 b}$ \\
\hline Luncheon & 33 & 94.3 & $0.7 \times 10^{2}$ & $2.7 \times 10^{2}$ & $1.68 \times 10^{2} \pm 0.11 \times 10^{2 \mathrm{~b}}$ \\
\hline
\end{tabular}

* Percentage in relation to total number of sample in each row. ${ }^{*}$ Standard error of mean

Table (7): Incidence of Coagulase Positive S. aureus in examined samples of fresh beef and meat products $(\mathrm{n}=35$ for each product)

\begin{tabular}{lllll}
\hline Sample & \multicolumn{2}{l}{ Positive } & No. of accepted samples** & No. of non- accepted samples** \\
& No. & $\% *$ & & \\
\hline Fresh beef & 6 & 17.1 & 29 & 6 \\
Minced meat & 9 & 25.7 & 26 & 9 \\
Sausage & 7 & 20.0 & 28 & 7 \\
Luncheon & 3 & 8.6 & 32 & 3 \\
Total & 25 & 17.9 & 115 & 25 \\
\hline
\end{tabular}

* Percentage in relation to total number of sample in each row. **Accepted and non- accepted samples according to (EEC, 2005).

(Normanno et al., 2007). The total aerobic and Enterobacteriaceae counts reflect the bacterial contamination and declared the hygienic quality of both raw meat and meat products. Meanwhile, Coliform counts may indicate faecal contamination either from human or animal sources and its presence indicate poor sanitation and handling (McEvovy et al., 2004; Paulsen et al., 2006).

The data shown in Table (1) revealed that the minimum and the maximum aerobic plate counts (APC) in the examined of fresh beef and meat products (minced meat, sausage and luncheon) were ranged from $7.3 \times 10^{4}$ to $9.9 \times 10^{4} ; 6.5 \times 10^{4}$ to $9.5 \times 10^{4} ; 2.8 \times 10^{4}$ to $8.9 \times 10^{4}$ and $2.5 \times 10^{4}$ to $7.9 \times 10^{4}$ respectively, with a mean value of $8.34 \times 10^{4} \pm 0.10$ $\times 10^{4} ; 8.03 \times 10^{4} \pm 0.12 \times 10^{4} ; 6.74 \times 10^{4} \pm 0.28 \times 10^{4}$ and $5.85 \times 10^{4} \pm 0.24 \times 10^{4}$, respectively. All examined meat samples $(100 \%)$ contained microorganisms. However, the counts were considered satisfactory as these results were lower than those suggested by EEC (2005). Nearly similar counts were recorded by Ahmed-Alyaa (2015); Hamed et al. (2015); Hassan and Soultan (2004); Paulsen et al. (2006).

The results in Table (2) appeared that, the minimum and the maximum Enterobacteriaceae count in the examined fresh beef and meat products( minced meat, sausage and luncheon )were ranged from $1.2 \times 10^{2}$ to $3.3 \times 10^{2} ; 1.1 \times 10^{2}$ to $2.9 \times 10^{2} ; \quad 1.2 \times 10^{2}$ to $2.7 \times 10^{2}$ and $1.0 \times 10^{2}$ to $2.6 \times 10^{2}$, respectively, with a mean value of $2.14 \times 10^{2} \pm 0.97 \times 10^{2} ; \quad 2.02 \times 10^{2} \quad \pm 0.76 \times 10^{2}$; $1.85 \times 10^{2} \pm 0.64 \times 10^{2}$ and $1.69 \times 10^{2} \pm 0.70 \times 10^{2}$, respectively. These results of were agree with those of Hassan and Soultan (2004); Stagnitta et al. (2006) and Gwida et al. (2014).

Data presented in Table (3) showed that, the minimum and the maximum Coliform count in the examined fresh beef and meat products (minced meat, sausage and luncheon) were ranged from 0 . $6 \times 10^{2}$ to $2.1 \times 10^{2} ; 0.5 \times 10^{2}$ to $1.3 \times 10^{2} ; 0.3 \times 10^{2}$ to $1.1 \times 10^{2}$ and $0.3 \times 10^{2}$ to $1.2 \times 10^{2}$, respectively, with a mean value of $1.25 \times 10^{2} \pm 0.13 \times 10^{2} ; 0$. $89 \times 10^{2} \pm 0.06 \times 10^{2} ; 0.73 \times 10^{2} \pm 0.08 \times 10^{2}$ and $0.71 \times 10^{2} \pm 0.07 \times 10^{2}$, respectively. These results came in parallel with those of Paulsen et al. (2006) Stagnitta et al. (2006); Ahmed-Alyaa (2015); AlMutairi (2011) and Hamed et al. (2015).

The results in Tables $(4 \& 5)$ revealed that, 21 isolates of E.coli were isolated from examined meat samples represented as $5(14.3 \%)$ from fresh beef with serotypes 2 O55:H7,1 O125:H18,1 O111: H4 and 1 O26:H11 ; 8(22.9\%) from minced meat with serotypes 3 O55:H7, 2 O125:H18, 1 O111:H4, 1 O26:H11 and 1 untyped; 6 (17.1\%) from sausage with serotypes 2 O55:H7, 1 O125:H18, 1 O111:H4, 1 O26:H11 and one untyped and two(5.7\%) from luncheon samples with serotypes O55:H7 . Moreover, 119 samples out of 140 ones were accepted, as they were free from E. coli isolates according to (EEC, 2005). Nearly similar results were obtained by Abd ElSalam-Azza (2014); Abdaslam et al. (2014); Maarouf and Nassif-Marionette (2008); Ramadan (2015); Tarabees et al. (2015). Meanwhile, these results were disagreed with those of EI Jakee et al. (2014); Elnawawi et al. (2012); Gwida et al. (2014); Nychas et al. (2008) and Kamal-Asmaa (2015). Moreover, the same serotypes of E.coli 
were previously isolated by Abd El-Salam-Azza (2014); Kalchayanand et al. (2012); Mohammed et al. (2014); Windham et al. (2013) and EI Jakee et al. (2014).

The obtained results in Table (6) revealed that, the minimum and the maximum Staphylococcus count in the examined fresh beef and meat products ( minced meat, sausage and luncheon ) were ranged from $0.7 \times 10^{2}$ to $3.8 \times 10^{2} ; 1.1 \times 10^{2}$ to $3.8 \times 10^{2} ; 0.7 \times 10^{2}$ to $3.3 \times 10^{2}$ and $0.7 \times 10^{2}$ to $2.7 \times 10^{2}$, respectively, with a mean value of $2.36 \times 10^{2} \pm 0.12 \times 10^{2} ; 2.67 \times 10^{2} \pm 0.11 \times 10^{2} ; 1.9 \times 10^{2}$ $\pm 0.11 \times 10^{2}$ and $1.68 \times 10^{2} \pm 0.11 \times 10^{2}$, respectively. These counts came in agreement with Phillips et al. (2006); Plaatjies et al. (2004) and Ahmed-Alyaa (2015).

The results obtained in Table (7) revealed that, 25 isolates of Coagulase Positive Staph. aureus was isolated from examined meat samples represented as $6(17.1 \%)$ from fresh beef; 9 (25.7\%) from minced meat; 7 (20.0\%) from sausage and 3(8.6\%) from luncheon samples. Moreover, 115 samples out of 140 ones were accepted, as they were free from Coagulase Positive Staph. aureus isolates according to (EEC, 2005). These results came in accordance with those obtained by Goja et al. (2013); Kanika et al. (2011); Maarouf and Nassif-Marionette (2008) and Hamed et al. (2015). Meanwhile, these results were disagreed with those of Abd El-Hady (2015); Abdaslam et al. (2014); EI Jakee et al. (2014) and Tarabees et al. (2015) who isolated S. aureus from raw meat and meat products with high incidence.

The present study failed to detect Salmonella serovars from all examined meat samples. These results were agreed with those recorded by Datta et al. (2012) and Abdel-Raouf et al. (2014)et al., (2014). Meanwhile, disagreed with those of Abdaslam et al. (2014); Maarouf and NassifMarionette (2008); Ramadan (2015) who isolated Salmonella from beef and meat products.

Finally, the present study proved that beef and meat products are considered public health hazard and the presence of aerobic bacteria; Enterobacteriaceae; coliforms; E. coli and Staphylococci Mainly Coagulase Positive Staph. aureus may be due to mishandling and the negligence of hygienic aspects either at production levels where most workers did not have medical certificates or selling of meat with expired dates. Therefore, it was concluded that E. coli and coagulase positive Staph. aureus are meat-borne pathogens of public health important.

\section{REFERENCES}

Abd El-Hady, M.F.A. 2015. Bacteriological and Molecular characterization of Staphylococcus aureus Isolated from Beef Meat Products in El Gharbia GovernorateM.V.Sc., Cairo Univ.

Abd El-Salam-Azza, S. 2014. Molecular detection of antimicrobial resistance for some food borne pathogensPh.D., Zagazig Univ.

Abdaslam, S.A., Hassan, M.A., Kaheel, H.A., Abobaker, T.M., Alnourain, T.H., Hamdan, H.A., Gokul Shankar, S., Thambirajah, J., 2014. Isolation of Escherichia coli O157 and other food borne pathogens from meat products and their susceptibility to different antimicrobial agents. Current Research in Microbiology and Biotechnology 2, 391397.

Abdel-Raouf, M., Nabil, M., El-Sayed, M., 2014. Antimicrobial Activities of Some Herbs Extracts on Food Borne Bacteria. J. American Science 10, 76-85.

Aberle, E.D., J., F., Gerrard, D.E., Mills, E.W., 2000. Principles of meat science, 4th ed. Hunt Puplishing Co., Kendall, USA.

Ahmed-Alyaa, S.O.S. 2015. Quality of Native and Imported Meat in The Egyptians MarketsM.V.Sc., Cairo University.

Al-Mutairi, M.F., 2011. The incidence of Enterobacteriaceae causing food poisoning in some meat products. Advanced J. Food Science and Technology 3, 116-121.

American Public Health Association "APHA", 1992. Compendium of Methods for the Microbiological examination of Foods, 3rd ed. The American Public Health Association, DC.

Balaban, N., Rasooly, A., 2000. Staphylococcal enterotoxins. Int. J. Food Microbiol. 61, 110.

Busani, L., Cigliano, A., Tailoli, E., 2005. Prevalence of Salmonella enterica and Listeria monocytogenes contamination in food of animal origin in Italy. J. food Protect 68, 1729 - 1733.

Datta, S.A., Akter, A., Shah, I.G., Fatema, K., Islam, T.H., Bandyopadhyay, A., Khan, Z.U.M., Biswas, D., 2012. Microbiological Quality Assessment of Raw Meat and Meat Products and Antibiotic Susceptibility of Isolated Staphylococcus aureus. J. Agric. Food Anal. Bacteriol. 2, 187-195.

Edward, R.P., Ewing, W.H., 1972. Edwards and Ewing's identification of Enterobacteriaceae, 3rd ed. Burgess, Minneapolis.

EI Jakee, J., Ata-Nagwa, S., Abd El-Moez-Sherein, I., Kandiel- Mai, M., Radwan- Nermin, M., 
2014. Assessment of the Prevalence of Salmonellae in Food. Int. J. Curr. Microbiol. App. Sci. 3, 30-42.

Elnawawi, F.A., Attala, O.A., Saleh, S., 2012. Enteropathogenes of public health importance in imported frozen meat and chicken. Inter. J. Microbiol. Res. 3, 59-63.

Food and Drug Administration "FDA", 2001. Center for Food safety and applied nutrition. www.FDA.org.

Gi, Y.L., Hye, I.J., In, G.H., Min, S.R., 2009. Prevalence and classification of pathogenic E.coli isolated from fresh beef, poultry and pork in Korea. International J. Food Microbiology 134, 196-200

Goja, A.M., Ahmed, T.A.A., Saeed, S.A.M., Dirar, H.A., 2013. Isolation and Identification of Staphylococcus spp. in Fresh Beef. Pakistan J. Nutrition 12, 114-120.

Gwida, M., Hotzel, H., Geue, L., Tomaso, H., 2014. Occurrence of Enterobacteriaceae in Raw Meat and in Human Samples from Egyptian Retail Sellers. . International Scholarly Research Notices 1, 6 .

Hamed, E.A., Ahmed, A.S., Abd El-Aaty, M.F., 2015. Bacteriological hazard associated with meat and meat products. Egypt. J. Agric. Res. 93, 385-393.

Hassan, H.F., Soultan, H.M., 2004. Some bacteriological quality of buffalo minced meat, in Giza governorate. J. Egypt. Vet. Med. Assoc. 64, 353 - 360.

ICMSF, 1996. Microorganisms in Food. I-Their Significance and methods of enumeration. 3rd Ed. Univ. of Toronto, Canada isolation from chicken giblets after pre-enrichment in buffered peptone water. J. Hyg. Camb. 87, 219.

International Organization of Standardization "ISO", 2001. Microbiology of food and animal feeding stuffs. Horizontal method for the enumeration of $\beta$ - glucuronidas- Positive E-Coli. Part 2: Colony- Count technique at $44^{\circ} \mathrm{c}$ using 5 bromo-4-chloro-3- indolyl $\beta$ D-glucuronide. 16649-2.

ISO, 2002. International Organization for Standardization. No.6579. Microbiology of Food and Animal Feeding Stuffs. Horizontal Methods for detection of Salmonella species.

Kalchayanand, N., Arthur, T.M., Bosilevac, J.M., Schmidt, J.W., Wang, R., Shackelford, S.D., Wheeler, T.L., 2012. Evaluation of commonly used antimicrobial interventions for fresh beef inoculated with Shiga toxinproducing Escherichia coli serotypes O26,
O45, O103, O111, O121, O145, and O157:H7. J. Food Prot. 75, 1207-1212.

Kamal-Asmaa, R. 2015. Detection and characterization of Escherichia coli from Different Meat SourcesM.V.Sc., Cairo Univ.

Kanika, B., Xiaogang, W., Susan, D., Marcus, Z., Liziane, R., Yifan, Z., 2011. MethicillinResistant Staphylococcus aureus in Retail Meat, Detroit, Michigan, USA. Emerg. Infect. Dis. 17, 1135-1137.

Kaper, J.B., Nataro, J.P., Mobley, H.L.T., 2004 Pathogenic Escherichia coli. Nature Reviews Microbiology 2 123-140.

Khan, J.A., Rathore, R.S., Khan, S., Ahmad, I., 2014. In vitro detection of pathogenic Listeria monocytogenes from food sources by conventional, molecular and cell culture method. Braz. J. Microbiol. 44, 751-759.

Leloir, Y., Baron, F., Gautier, M., 2003. Review: Staph. aureus and food poisoning. J. Genetics and Molecular Research 2, 63 - 76.

Llewelyn, M., Cohen, J., 2002. Super antigens: Microbial agents that corrupt immunity. Lancet. Infect. Dis. 2, 156-162.

Maarouf, A.A., Nassif-Marionette, 2008. Bacteriological studies on frozen cow meat and some meat products at Benha city. Journal of the Egyptian Vet. Med. Assoc. 68, 129-141.

Madden, R.H., Espie, W.E., Loran, L., McBride, J., Scates, P., 2001. Occurrence of Escherichia coli O157: H7, Listeria monocytogenes, Salmonella and Campylobacter Spp. On beef carcasses in Northen Ireland. Meat Sci. 58.

McEvovy, J.M., Sheridan, J.J., Blair, I.S., McDowell, D.A., 2004. Microbial contamination on beef in relation to hygiene assessment based on criteria used in EU Decision 2001/ 471/ E.C. Int. J. Food Microbiol. 92, 217 - 225.

Mohammed, M.A., Khalid, I.S., Elsaid, A.E., Asmaa, M.A., Tomohiro, T., 2014 Occurrence, serotypes and virulence genes of non-O157 Shiga toxin producing Escherichia coli in fresh beef, ground beef, and beef burger. J. Food Control 37, 182187.

Normanno, G., La Salandra, G., Dambrosio, A., Quaglia, N.C., Corrente , M., Parisi, A., Santagada, G., Firin, U.A., Crisetti, E., Celano, G.V., 2007. Occurrence, characterization and antimicrobial resistance of enterotoxigenic Staphylococcus aureus isolated from meat and dairy products. 
International J. Food Microbiology 115, 290-296.

Nychas, G.J.E., Skandamis, P.N., Tassou, C.C., Koutsoumanis, K.P., 2008. Meat spoilage during distribution. J. Meat Science 78, $77-$ 89.

Park, C.E., Akhtar, M., Rayman, M.K., 1994. Evaluation of commercial enzyme immunoassay kit (RIDASCREEN) for detection of staphylococcal enterotoxins A, B, C, D, and E in foods. Appl. Environ. Microbiol. 60, 677.

Paulsen, P., Schopf, E., Smulders, F.J.M., 2006. Enumeration of total aerobic bacteria and E.coli in minced meat and on carcass surface samples with an automated most-probablenumber method compared with colony count protocols. J. Food Protect 69, 2500 - 2503.

Phillips, D., Jordan, D., Morris, S., Jenson, I., Sumner, J., 2006. A national survey of the microbiological quality of beef carcasses and frozen boneless beef in Australia. J. food Prot. 69, 1113-1117.

Plaatjies, Z., Lues, J., Buys, E., 2004. Staphylococcal growth in fresh vacuumpacked red meat at various storage conditions, In: 8th World Congress on Environmental Health, Durban, South Africa.

Prescott, M., Harley, P., Klein, D.A., 2005 Microbiology, 6th ed. McGraw Hill, New York USA.

Quinn, P.J., Markey, B.K., Carter, M.E., Donnelly, W.J.C., Leonard, F.C., Maguire, D., 2002. Veterinary microbiology and microbial disease. Iowa State Univ. Press, Blackwell Science Ltd.
Ramadan, A.M. 2015. Contamination of meat products with human pathogensM.V.Sc. , Alex. Univ.

Snedecor, G.W., Cochran, W.G., 1969. Statistical Methods. 6th Ed. Iowa State University Press, Asmes, USA.

SPSS, 2001. SPSS for windows, Version: 11. Copyright SPSS Inc. 1989 - 2001. All rights reserved.

Stagnitta, P.V., Micalizzi, B., Guzmán, A.M.S., 2006. Prevalence of some bacteria yeasts and molds in meat foods in san Luis, Argentina. Cent. Eur. J. Publ. Health 14, 141-144.

Synge, B.A., 2000. Verotoxin producing E.coli: veterinary view. J. Applied Microbiol. Symposium Suppl. 88, 315-375.

Tarabees, R.Z., Hassanin, Z.H., El-Bagoury, A.M., 2015. Polymerase Chain Reaction (PCR): An Alternative Rapid Method for Detection of Some Microbial Contamination of Meat Products. Alexandria J. Veterinary Sciences 45, 91-98.

Windham, W.R., Yoon, S.C., Ladely, S.R., Haley, J.A., Heitschmidt, J.W., Lawrence, K.C., Park, B., Narrang, N., Cray, W.C., 2013. Detection by hyperspectral imaging of shiga toxin-producing Escherichia coli serogroups O26, O45, O103, O111, O121 and O145 on rainbow agar. J. Food Prot. 76, 1129-1136.

Zafar, A., Ahmed, E., Wajiha, H., Khan, A., 2016. Microbiological Evaluation of Raw Meat Products Available in Local Markets of Karachi, Pakistan. Pakistan Academy of Sciences B. Life and Environmental Sciences 53, 103-109. 